\title{
Medicinal Product Name
}

National Cancer Institute

\section{Source}

National Cancer Institute. Medicinal Product Name. NCI Thesaurus. Code C142607.

The name assigned to a medicinal product as approved by a regulatory authority of the country of authorization. 